https://doi.org/10.3126/pragya.v7i1.35041

\title{
Significance of Hindu Pilgrimage; study of Pashupathinath and Kashi Vishwonath
}

Dahal Bishnu Prasad, PhD

\begin{abstract}
Pilgrimage is one of the most common phenomena found in religious culture, occurring in just about every major religious tradition. Pilgrimage has adapted to a purportedly secularizing world, and even benefited from contemporary modes of transportation and communication.All pilgrims provide the message of human welfare, development of universe and religious and spiritual promotions for the welfare of society, way to truth, salvation and many more through interactions, observations of pilgrimage, but for understanding the cultural system in both intrinsic and extrinsic ways, or as insider and outsider, a human science paradigm would be better as it covers the totality thus attempting to reveal the "whole" of the culture, human psyche and functions at play. It was found that no any kind of discriminations, differences, inequalities on the basis of caste, class, gender, ethnicity etc.among pilgrimage during the visit. Almost all respondents felt the harmony, cohesion and friendly during the visit though cross-border. All Shiva shrines promote the welfare of animals, human and the world. Harmony, cohesion, solidarity and brotherhood and sisterhood were found good. Any kind of discriminations, differences, inequalities were not found on the basis of caste, class, gender, ethnicity etc.
\end{abstract}

Key words: Hindu, pilgrimage, Kashi, Kathmandu, Passupathinath, Vishwonath .

\section{Introduction}

Pilgrimage is a sacred act and practice with its ancient and divorce origins as well as its description and different references in the sacred texts and other allied literature, continued to be popular among the Hindus (Singh, 1997). After Vedic period, the practice of pilgrimage have been practiced as a cultural, religious and social with traveller's perspective stands as important part of socialization, interactions and cultural exchanges of different society, culture and country. Pilgrimage is considered as a sacred act, sacred aim and sacred devotions, faith with certain specific objects to fulfill the desire of obtaining 'Punya' and to get rid of 'Paap' (Sin) in the course of lifetime for all.

In Hindu pilgrimage, basically in Lord Shiva Temples of Nepal and India, the sacred centers generate a complex network of socio-religious elements regulating the entire Hindu population. The number of Hindu sanctuaries in Nepal and India are so large and the 
practice of pilgrimage is so popular that the whole of cross boarder Hindu pilgrimage can be regarded as vast sacred classical Hindu epic texts organized into a system of pilgrimage centre of varied importance. Now, it is importantly emphasizing the role and significance of cross border travel in the name of visiting Hindu pilgrimage linguistically, geographically, regionally and social diversity of cross-border geography to minimize the multidimensional role differences, misunderstanding, cultural lag and interactions through the sacred centers and the organization of different centers of pilgrimage (Dubisch, 1995). That's why pilgrimage is a kind culture of networking people in utopian supercenters which reinforce religious percepts but also impress pilgrims with vastness, the diversity and seemingly paradoxically the oneness of the society.

Nepal is known as the Land of Gods and Kathmandu is known as a city of temples (Neuupane, 2019). Therefore, many spiritual people from all over the world travel to visit pilgrimage places in Nepal. There are various god and goddess based Hindu Temples and holy places in Nepal and India. Among them Pashupatinath temple and Vishwonath temples are the greatest among all in Shivaism.

Lord Shiva is a Hindu deity worshipped by Hindus of all over the world as the destroyer of ignorance. Shiva is the god of all and is worshipped by all, including gods like Brahma, Vishnu,Indra and even of demons. Amongst all the gods in the Hindu pantheon, Shiva stands as superior whose temples dedicated to his worship in Nepal and India (and abroad). The most prominent of these are the Pashupatinath temple in Kathmandu and Vishwonath temple in Varanashi, where Hindus worshipped Shiva. In this study, the cultural assimilation, religious assimilation and diffusion of various religious and cultural components like- the pilgrims carry on the many cultural and religious values from pilgrimage; worshhing processes, chanting rules, lightening lights etc. were borrowed from pilgrimage by pilgrims; some of them were knowingly and; some were unknowingly were studied.

In this regards, studies of pilgrimage contribute substantially to maintain and to modify the prevailing socio-cultural systems based on religions and also to facilitate the interrelationships amongst the members of different societies, within Hindus. Hence anthropologists study pilgrimage not as only the religious institutions, it has wider scope and it has greater significance on socio-cultural dimensions (Dubisch, 1995) like norms, attitudes, values, behaviors, everyday life patterns, religious activities.

\subsection{Kathmandu to Kashi}

Among many pilgrimages of Lord Shiva Shrine in India and Nepal, the travel to Kashi from Kathmandu is most popular route of pilgrimage travel for Nepalese pilgrims including 
all over the country. This travel is mainly for those pilgrims who believed Shivism and worship Lord Shiva mainly among Hindu god and goddess. There are two great Siva shrine in India and Nepal; Pashupatinath and Vishwonath.

Kashi Vishwanath Temple is one of the most famous Hindu temples dedicated to Lord Shiva. It is located in Varanasi, Uttar Pradesh, India. The Temple stands on the western bank of the holy river Ganga, and is one of the holiest temples of Lord Shiva. The main deity is known by the names Shri Vishwanath or Vishveshvara literally meaning Lord of the Universe. Varanasi (popularly, Banaras) city is also called Kashi in ancient time, and hence the Temple is popularly called as Kashi Vishwanath Temple (Bhardwaj, 1973). The etymology of the name Vishveshvara is Vishva: Universe, Ishvara: lord, one who has dominion (Shastri, 1950). The Temple has been referred to in Hindu scriptures for a very long time as a central part of worship in the Shaivasim philosophy within Hindus.

Pashupatinath Temple is one of the most greatest and famous Hindu temple of Lord Shiva, where Shiva is worshipped as the Lord of all living creatures. Pasupat-Chhetra (site of Pashupatinath) is one of the holiest places in Nepal for Hindus all over the world. Pashupatinath Temple, which is dedicated to Lord Shiva - one of the Trimurtis or the holy trinity, is the major attraction of this area. This pagoda-style temple has a golden pinnacle at the top. Worshipped as the guardian deity of Nepal, Pashupatinath literally means the lord of animals (Nyaupane, 2019).

Many Hindu Pilgrims comes to Pashupatinath round the year. Hundreds of thousands of Hindu from all over World make Pilgrimage on the day of Shivaratri (Night of Shiva, one day before black moon in February).

This article attempts to explore the connections between the Hindu pilgrimage of Lord Shiva between the countries India and Nepal. In course of study when visit to Pashupatinath and Kashi Vishwonath most of key informants who are associated with respective temples authorities have mentioned strongly emphasizing the significance of pilgrimage only on to complete the course of travelling routes of two Shiva temples located in India and Nepal(Bhardwaj, 1973). Among them one administrator in Kashi Vishwonath temple said that when a pilgrims visit only one temple of Lord Shiva it is incomplete and avisit to holy Kashi Vishwanath Temple is forever incomplete without a visit to Pashupatinath Temple and vice versa). It shows the mutual reciprocal cultural, religious pilgrims's interrelationships between the Hindu pilgrimages of the Lord Shiva situated in Nepal and India (Bhardwaj, 1973). Varanasi retains its identity as a centre for religious pilgrimage for many reasons, and one of the biggest reasons is the link between Kashi Vishwanath and Pashupatinath. 
The significance of Kashi Viswanath Temple and Pashupatinath Temple is interlinked especially in relation to Hindu faith. Situated on the banks of the Bagmati River, north-east of Kathmandu Valley, Pashupatinath Temple is considered to be the "head" meaning head of Lord Shiva, while Kashi Viswanath Temple is considered to be the "body without head". Thus, the success of pilgrimage to worship Shiva in true sense of the divine Lord Shiva is considered incomplete without worshipping both temples.

One of the most special features of the Shivalinga in Pashupatinath, Nepal, is that the linga has five head: the east facing Tatpurusha, the north facing Ardhanarishwara (Vamadeva), the west facing Sadyojata, South facing Aghora, and the upward facing Nirakara.

In the epic war of Mahabharata, the Pandavas defeated their cousins by killing them. In their minds, they had committed gotra hatya, also known as fratricide, and Brahmanahatya (the killing of priest class Brahmans)(Shastri, 1950). They wanted to repent for their sins. To continue on their path of atonement, they gave up their reigns of their kingdom their kins and went to Shiva for his blessings. At first, they went to Kashi, or also known as Varanasi, which is supposed to be the favorite city of Shiva and is famous for its Shiva temple. However, Shiva had been deeply enraged by the dishonesty and death in the war of Mahabharata (Bhardwaj, 1973). So, their prayers had no effect on Shiva as he was insensitive to it. He even transformed himself into a bull and hid in the Garhwal region. The search for Shiva in Kashi, thus, went in vain.

The Pandavas then went to Garhwal Himalayas. Bhim standing between two mountains started to look for Shiva when he found a bull grazing near Guptakashi (hidden Kashi). He immediately knew that the bull had to be Shiva, and so he went to the bull and caught the bull by its tail and the legs. But Shiva disappeared into the ground, later reappearing into parts, with the hump in Kedarnath, the arms in Tunganath, the navel and stomach in Madhyamaheshwar, the face in Rudranath, the head in Pashupatinath. Seeing this, Pandavas built temples at five different places to worship and venerate(Bhardwaj, 1973) Shiva and so that their sin is forgiven. Having been pleased with their new actions, Shiva granted them their wish and freed them from their sins.

Another version has it that Bhim not only caught the bull but also stopped it from disappearing, which resulted the bull to be torn into five parts and spread across five locations. After that, Pandavas meditated to Kedarnath for salvation, performed yagya and also practiced Mahapath (known as Swargarohini) to free themselves(Bhardwaj, 1973). 


\subsection{Religious ties between Shiva temples}

Shiva temples of India and Nepal tied the people, culture, society and relations, geographically, socially, culturally and historically. Relationships based on various aspects like cultural, religious, educational, political, and economic between India and Nepal is in multilateral and the nature of relationship is unique of friendship and cooperation characterized by open boarders and deep rooted people to people contact of kinship and culture. Nepali priest serving in Kashi Vishwanath Temple and Indian priest in Pashupatinath temple, Kashi being the one of the major religious destination for each of the old age people of Nepal, Kathmandu and Varanasi considered as sister city relations with each other, Ganga Arati of Varanasi is followed in Pashupatinath temple on the bank of Bagmati river (Bhardwaj, 1973). This shows the strong religious relation, besides this Varanasi was and is the major destination of Nepali students for higher education.

This paper aims to identify what types of religious borrowings, mutual exchanges of religious, spiritual materials, cultural assimilations and social solidarity through religious exchange during the pilgrims in Vishwonath, and Pashupatinath.

\section{Theoretical Review}

However, from the overview of the references related to pilgrimage, I have found one which include an array of important studies that have provided a background has supplemented my own personal experiences I tried to explore and experience the religious, spiritual beliefs based on holy shrines of Lord Shiva temple of Nepal and India as a social construction of meaning in a society which, although permeated by a huge influx of pilgrimage every year, has nevertheless maintained pre-modern, traditional beliefs and practices. The pilgrimage on Hindu temple despite provides a window to a distant past that I have now can experience such opportunity to identify the religious and spiritual world no longer experience so directly in many places on earth.

The key analytical aspect from Geertz's thick description is the broader socio-cultural and political-economic context of religious ceremonies as opposed to secular games, that background is available (Peacock, 2005). It is deeper both methodologically and in terms of the subject matter especially, a religious and spiritual ritual that calls upon the most powerful of all the gods to sustain life on this planet. The main concept of thick description helps to link Geertz's anthropological analysis to Symbolic Interactionism and a broader notion of anthropological interpretive. According to the anthropologists 'thick description' or 'great tradition” means usually text based Hindu religious practices such as Gita, Puran, Ramayan, Mahabharat etc and the thin description or "little tradition" means a residual set 
of practices, associated by divinities and spirits not found in the great tradition and both are for the liberation of human.

Most Symbolic Interactionist research has involved the study of sub-cultures and small groups in today's societies. Some Symbolic Interactionists are interested in sexuality and may want to consult anthropological studies to get a sense of the wide variety of sexual practices and sexual identities found around the world (Lyons and Lyons, 2004). But the study of religious ritual has not been a key part of Symbolic Interactionist research, especially rituals involving quite different sets of religious beliefs. So, Blumer (1954), on sociological theory, mentions that there are two legitimate forms; symbolic interactionism and interpretive theory.

Here, I like to synthesis the core concepts of thick description propounded by Geertz as a theory to visualize the overall significance of religious and spiritual world in one hand and in another hand how pilgrims get salvation, mental peace and how they find the path nearer to the god and Devine are studied with the help of Victor Turners' theoretical framework. The concern in anthropology with the social process of pilgrimage comes directly from assumptions about the symbolic and structural attributes of such events, and especially regarding the presence or absence of "structure", "anti-structure", "communitas" and "liminality" (Turner, 1974).

Structure is 'a more or less distinctive arrangement of mutually dependent institutions and the institutional organization of social positions and/ or actors which they imply" (Turner, 1974). Social structure such as Hindu caste or economic class are species of structure which produce "distance and inequality" between people (Turner, 1974). Similarly, anti-structure, by contrast, is defined as that which "trends to ignore the reserve, cut across, or occur outside of structural relationships"(Turner, 1974). Structure "holds people apart, defines their differences, and constraints their action", anti-structure is essentially egalitarian, "representing the desire for a total, unmediated (i.e., unstructured) relationship between person and person" (Turner, 1974).

Turner's theory to study in case of Hindu pilgrimage is appropriate in visualizing the anticaste, class and gender structure, which is against the caste system and Hindus strictly follow the caste based structure but they do not follow such structures in pilgrimage behavior juxtapose to Turner's anti-structure and according to turner, anti-structure is expected in and is exemplified by religious pilgrimage behavior.In case of Hindu pilgrimage there are no any caste, class, ethnicity, gender based hierarchy. So the transplant of Turner's theory to study the pilgrimage is inappropriate in caseof Hindus. 
In this study, though there are hierarchies in orthodox Hindu society, in general ritual and cultural worship, but in case pilgrims there are no any hierarchies,in terms of caste, class, gender and so on. The theory of thick description by Geertz and the theory of Victor Turner's anti-structural notion can be juxtaposed in the context of pilgrims visit on pilgrimage in orthodox,, structured, hierarchical Hindu society. No one can restrict anybody to visit pilgrimage and there is no any hierarchy found in Hindu pilgrimage.

\section{Methodology}

The methods of data collection are purely based on ethnographic fieldwork of Pashupatinath in Kathmandu, Nepal in 2019, May and Vishwonathin Kashi, India, in September, 2019, the study areas of the present research on which this article is based.An appropriate anthropological tools and techniques selection is important according to the research topic and nature of the respondents. The present study covers the two important Shiva temples among which two are situated in India and one in Nepal. The main focus of study will be on pilgrims who are visiting to Pashupatinath and Vishwonathon pilgrimage from different parts of the India and Nepal. Here, respondents were selected as the visitors of Pashupathnath temples from various parts of India and the visitors of Kashi Vishwonath from the various parts of the Nepal to study the importance, significance of religious faiths, traditions, cultures in pilgrims way of life them after the visit. How they adopts the religious beliefs in their everyday life. The analysis is mainly drawn from the facts, information, and data from the Nepalese pilgrims who visited Kashi Vishwonath temple and returned back in Nepal irrespective of their caste, creed, sect, religion, language, age, sex, education and income group and in case of Indian pilgrims who visited Pashupatinath temple were selected the respondents. This study also concerns about sacred specialists (temple priests) of Pashupatinath and Vishwonath to known about the information about the temples.

To make study scientific, easy and reliable, sample should be selected because it is very difficult to study whole universe according to the research topic to make study generalizable. For this study, I have adopted stratified random sampling method for selection of informants for data collection. Openended questionnaires were also administered to the educated pilgrims and necessary data were collected.

100 samples were selected, out of which 50 samples from each temples were selected among which priests,the sacred specialists, cases of different types of shop keepers, and administrators of temples were asked questions. Data like attitudes, feelings of pilgrims, worshiping and visiting temples and places patterns, processes to visit temple, rules and regulation of temples, behaviors of priests etc. were collected by using various methods, 
tools and techniques such as semi-structured, structured interview schedules, observation, interview, case-study. The non-participant type of observation was carried out to identifying the situations, relations and its impacts of continuity and change in attitudes, behavior and practices. Both individual and group interviews were conducted toexplore theinformation regarding the family travels, their perceptions, the changes in behaviors and attitude after the pilgrimages. Key informants (concern temple and pilgrimage authorities) were asked the key questions related with the respective temples their origin, nature of visitors and their behaviors.

\section{Results and Discussion}

On the basis of the respondents' answers on research topics with various structured and unstructured and open ended questions.It is found that the most of the respondents presented their views which are discussed in this section. In view of cultural anthropologists' perspective, pilgrimage is an informal religious institution functions as a part of society to impart religious philosophy, concepts to people of that particular society or religion through the visit of new religious sects, worlds and society to generate, interact and socialize knowledge which helps to guide and facilitate their everyday life spiritually. In this study, respondents gave a clear version on the how pilgrimage acts as institution to socialize, to control their behavior religiously or spiritually and how they change themselves after visit various pilgrims.

The sacred journey for spiritual purpose is to worship, seek the truth and to visit a site where a significant religious event happened is a pilgrimage. Hindus have many different important sites of pilgrimage associated with stories of gods and goddesses.

\subsection{Pilgrimages promote cohesion and solidarity}

It was found from the study that, most of the respondents felt that pilgrimages play vital role to enhance the social solidarity, and social cohesion because it has been an important mechanism, processes, and culture of the Hindu ritual and spiritual practices since Vedic times. In many respects they contributed to the growth, and promote one culture to another. It was found that the culture of Kathmandu diffuse to Kashi by modifications and vice versa. In the process, they contributed to the preservation, expansion, exchange and promotion of Hinduism, elevating the character and consciousness of its people, uniting them into one doctrine despite their regional and cultural diversity, and creating feelings of belongingness and brotherhood. 


\subsection{Manifestation of faith and devotion latent of salvation}

Hindu pilgrims stand testimony to its ancient past and spiritual distinction. They also stand witness to the living presence of God in numerous forms and guises all over the Indian subcontinent. Pilgrim sites and pilgrimages played an important role in unifying the religiously oriented people in particular culture, despite its geographical, cultural diversity and social differentiations.

Hinduism pilgrims in Indian subcontinent survived despite intense social, political, and religious pressure and conflicts ultimately credit to the promotion of all pilgrimages in Hindu spiritual and religious practice. The earliest reference to them can be found in the Rigveda itself, and Hindu spiritual teachers and gurus made them the focal point of their activities and teachings for generations. Nowadaysvisit pilgrimages is easier task because of physical facilities and development of transports, but there was a time when going on pilgrimage meant risking a near certain death. They tested the strength of one's faith and devotion, since most pilgrim sites used to be in remote and inaccessible places, and to reach them one had to pass through difficult terrains and dense forests, risking their lives. In case of Kashi from Nepal and Pashupatinath in Kathmandu from all over the India was a part of that religious travel.

Hindu Pilgrimages especially the shrine of Lord Shiva are beneficial both mentally and spiritually. They are superior and an important part of Hindu ritual and devotional worship. Devotees go on pilgrimages to fulfill their vows or perform their obligatory duties such as marriage, initiation or tonsure ceremony. The respondents shared their concepts the pilgrimages based on the Lord Shiva are undertaken to atone for past sins or express gratitude and they also go on pilgrimages to holy sites to mix the ashes of their deceased relations to help them obtain a good birth in next life or ensure their safe journey to the next world because Lord Shiva stands as supreme god in Hindu world view and the most important reason to select the Pashupatinath and Vishwonath pilgrimage importantly.

\subsection{Concepts of purity and pollution}

In Hindu worship, pilgrimages or tirtha also refers to sacred water, which is collected from a river, natural spring, tap or a sacred pond and ritually sanctified for worship and cleansing. Most Hindu pilgrim places are located on the banks of rivers, natural spring, and natural tap and or near water ponds, where pilgrims can take a holy bath before entering the temples and seeing their favorite deity to worship. The association of holy bath with water is not new, but it is found in the ancient tradition too. Holy water cleans the human body, while pilgrimages are meant for spiritual cleansing 
Customarily and traditionally these attributes are associated with pilgrim places which happen to be upon the banks or near rivers and water bodies or on the top of a hill or a mountain. It is also often used as a title or an epithet to refer to divine beings or pious people, as in case of being pure.

\subsection{Pilgrimage a wayto understand the nature and the world}

The success of human life is to understand the nature and the world. In a wider context, pilgrimages provide the way to know, struggle and serve our essential nature and our highest purpose upon earth. The majority of respondents believed that the symbol of web of mortal life understood more when one in pilgrimage rather than in everyday life. Usually, pilgrimage is a spiritual journey in search of liberation and the final destination is the immortal heaven, upon reaching which no one returns. In Hinduism, pilgrimages remind this singular truth for all and pilgrimage as means to undertakefor a number of purposes, but as the scriptures say the best ones are those which are undertaken to express love and devotion to God rather than for selfish motives. According to Hindu beliefs, the images which people worship in temples and at holy places are not lifeless images, and embody the power of the deity. Hence, gods inside the temples are considered living incarnations, whose power increases in proportion to the attention and offerings they receive and the devotees outside the temple to worship god to take care of this world. It means gods grow in strength and power and contribute to the welfare of the world if a large number of devotees keep visiting the holy sites and worship with ritual offerings.

\subsection{Spiritual significance of pilgrimage}

Ritually and spiritually, pilgrimage has great significance; they are essentially holy places, which are sanctified by the presence of God; and which symbolize purity and divinity, in an otherwise impure world. They also play an important role in the preservation and continuation of our faith, as they draw worldly people and strengthen their devotional fervor and religiosity.

Thus, pilgrimages serve an important purpose in our lives, by practicingmerit making (Dharma) and keep our gods happy and nourished through offerings.Pilgrims in Nepal and India are considered a sacred land because it is home to numerous deities, saints and seers. They are wide spread all over and every year, millions of people go on pilgrimages to visit them and seek their blessings. In the process, many people society and cultures are benefited; some host society materially through trade and guest through spiritually and religiously. 
Although, pilgrimages have a symbolic meaning parallel with the spiritual journey of individual souls upon earth, they form a part of the Hindu ritual worship in one hand and in another hand, it is still a part of the knowledge concepts and perceptions, which are helpful to gain a good birth in next life, but not closely associated with achieving liberation in the mortal world. In this regards, one should practice virtues, detachment, renunciation, sameness, etc. to cultivate purity and become pure to achieve oneness with the supreme self.

In response toquestions therespondents about the purpose of your pilgrimage, most of the respondents justified as going on pilgrimage tours and seeing the places of spiritual importance is to meet other saintly people who follow a spiritual path and see how they live. This is especially the case with saints and sages who can help us by giving their association and sharing their spiritual knowledge and realizations. This is of prime importance for us in order to align our lives in a similar manner so we can also make spiritual progress.

Pilgrimage is a sacred journeyto encounter, see, and experience the divine. This is accomplished by associating with holy people, holy places of previously the divine have taken place, and where the sacred temples allow darshan: the vision of the supreme. Darshan is the process of approaching the deity in the Temple in a state of spiritual communication, open and ready to receive sacred revelations. It means to see the absolute reality, and also to be seen by that supreme reality, god.

\subsection{Religious enlighten, salvation and way to heaven}

The religious aim of pilgrimage is going toward what is holy and most sacred, and remaining focused on the opportunity of having a life-changing experience. In this way, people undergo voluntary austerities for purification to relieveof lifetimes of fate (karma). This process will help to change in consciousness and perception of spiritual identity, to world view and help to access the spiritual dimension through enlightenment. Generally, it refers to an eminent teacher or philosopher, ascetic, saint or sacred preceptor. During pilgrimage the harmony with divine helps to experience the spontaneous help from many people and also believed that in such a state of consciousness, and feeling obstacles disappear quickly. In a way, it is divine guidance that assistsin mission and prepares for higher and higher levels of spiritual perception and it is another form of experiencing the divine and the spiritual progress. The objective of pilgrimage takes on more meaning when we realize the purpose of life. Life is meant for becoming free from the life cycle in this world, which means the continuous cycle of birth and death. 


\section{Conclusion}

Religious pilgrimage follows the social norms of equality, equity and humanitarian approach in society and culture, but it also follows idiosyncratic to Hindu religious system. It is found from the research that, with the travel in religious pilgrimage sites the large numbers of pilgrims were and a widespread interest in visit holy places for salvation incarnation with their own perspectives. Exchange of mutual pilgrims of Hindu pilgrimage in both Nepal and India found ultimate development of harmony, sharing culture, exchange their concepts, in a way. The cultural relationships promote harmony among the Hindus of both countries. In India Hindus are more pressurized by the expansion of Islam movement, while Nepal is not facing such religious pressure by Christian though they are increasing, but now undue pressure from Hindu to Muslim is also felt. In Nepal religious syncretism between Hindus and Buddhist promotes the religious respects among religions, but it was not found in case of India. Indian Hindus treat Nepalese pilgrims as inferior in core value of Hindu worlds view as they are superior.

\section{References}

Bhardwaj, S.M. (1973). Hindu Places of Pilgrimage in India, Berkeley: University of California Press.

Blumer, H.(1954). What is wrong with social theory? American Sociological Review, 19: 3-1.

Dubisch, J. (1995). In a different place: pilgrimage, gender and politics at a Greek island shrine. Princeton: Princeton University Press.

Geertz, C. (1973), The Interpretation of Cultures, Basic Books Inc.

Lyons, A. P. \& Lyons, H.D. (2004). Irregular connections: A history of anthropology and sexuality. Lincoln, NE: University of Nebraska Press.

Nyaupane, P. (2019). Cultural heritage tourism in Pashupatinath area,Journal of Nepal Mountain Academy, Kathmandu: Nepal Mountain Academy, College of Mountaineering, 1, 86- 102.

Peacock, J. (2005). Geertz's concept of culture in historical context: how he saved the day and maybe the century, pp. 52-62 in Sweder, Richard A. and Byron Good (eds.) Clifford Geertz by his colleagues. Chicago: University of Chicago Press.

Shastri, J. L. (1950), Siva Purana, Part 1-4, Motilal Banarsidass

Singh, Rana P.B. (1997). 'Sacred space and pilgrimage in Hindu society: the case of Varanasi', in R.H. Stoddard and A.Morinis (eds) Sacred Places, Sacred Spaces: The Geography of Pilgrimages, Baton Rouge, LA: Louisiana State University Press.

Turner, V. (1974).Pilgrimage and communitas, Studia Missionalia, 23, 305-327. 